\title{
KARAKTERISASI SIFAT OPTIK LAPISAN TIPIS ZnO:Al PADA SUBSTRAT GELAS UNTUK JENDELA SEL SURYA
}

\author{
Wirjoadi, Yunanto, Bambang Siswanto, Sri Sulamdari, Sudjatmoko \\ Puslitbang Teknologi Maju - BATAN \\ Jl. Babarsari Kotak Pos 1008, Yogyakarta 55010
}

\begin{abstract}
ABSTRAK
KARAKTERISASI SIFAT OPTIK LAPISAN TIPIS ZnO:Al PADA SUBSTRAT GELAS UNTUK JENDELA SEL SURYA. Telah dilakukan karakterisasi sifat-sifat optik lapisan tipis ZnO:Al pada substrat gelas untuk jendela sel surya dengan metode sputtering. Penelitian ini bertujuan untuk memperoleh lapisan tipis ZnO:Al yang dapat digunakan sebagai bahan TCO (Transparent Conducting Oxide) untuk sel surya silikon amorf. Untuk mendapatkan lapisan tipis ZnO:Al dengan sifat optik optimum, proses deposisi dilakukan dengan beberapa variasi parameter, yaitu variasi konsentrasi campuran Al, suhu substrat, tekanan gas dan waktu deposisi. Berdasarkan hasil eksperimen yang telah dilakukan diperoleh hasil lapisan tipis ZnO:Al yang optimum pada kondisi suhu $450{ }^{\circ} \mathrm{C}$, tekanan gas $6 \times 10^{-2}$ torr dan lama waktu deposisi 1,5 jam. Dari pengukuran sifat-sifat optik (transmitansi) dengan UV-vis diperoleh hasil optimum pada suhu $450^{\circ} \mathrm{C}$. Pada kondisi ini transmitansinya sekitar (50-82) \%, pada tekanan gas $6 \times 10^{-2}$ torr sekitar (50-80) \% dan pada waktu deposisi 1,5 jam sekitar (49-81) \% yang semuanya pada posisi panjang gelombang (500-800) nm. . Untuk lapisan tipis $\mathrm{ZnO}$ diperoleh hasil transmitansi sekitar (78 - 80) \% pada posisi panjang gelombang (500-800) $\mathrm{nm}$. Hasil foto dengan SEM, untuk lapisan tipis $\mathrm{ZnO}$ diperoleh tebal lapisan sekitar 1,5 $\mu \mathrm{m}$, morfologi permukaan dan butiran-butiran kecil terdistribusi secara homogen. Sedangkan untuk lapisan tipis ZnO:Al diperoleh tebal lapisan sekitar 1,3 $\mu$ m dan morfologi permukaan yang terbentuk dengan butiran-butiran yang tidak seragam.
\end{abstract}

\begin{abstract}
Characterization of thin film optic properties of ZnO:Al on glass substrate for solar cell window. It has been characterized a $\mathrm{ZnO}: \mathrm{Al}$ thin film growth using sputtering technique for solar cell window. The aims of this research is to get a $\mathrm{ZnO}$ :Al thin film that can be used as a TCO (Transparent Conducting Oxide) on amorphous silicon solar cell. To get an optimum properties, deposition process has been done for various parameters, such as composition/concentration of Al, substrat temperatur, gas pressure and deposition time. Based on experiments result, it's found that the optimum result was achieved at temperatur $450{ }^{\circ} \mathrm{C}$, gas pressure $6 \times 10^{-2}$ torr and time 1,5 hours. From optical properties (transmitance) measurements using $U V$-vis, it was found that the optimum results was achieved at temperatur $450{ }^{\circ} \mathrm{C}$. At this conditions, wave length (500-800) $\mathrm{nm}$, the transmitance was (50-82) \%, at pressure $6 \times 10^{-2}$ torr the transmitance was (50-80) \% and at deposition time 1,5 hours was (49-81) \%. For $\mathrm{ZnO}$ thin film, was at wave length (500-800) $\mathrm{nm}$, the transmitance was (78 - 80) \%. From micro structure analysis using SEM, it was found that the thickness layer of $\mathrm{ZnO}$ was 1,5 $\mu \mathrm{m}$ and 1,3 $\mu \mathrm{m}$ for $\mathrm{ZnO}: \mathrm{Al}$. While from surface morphologi it was found that for $\mathrm{ZnO}$ thin layer the grains was distributed homogenously, while for ZnO:Al the grains was distributed unhomogenously.
\end{abstract}

\section{PENDAHULUAN}

$\mathrm{P}$ ada tahun terakhir ini sel surya silikon amorf (a-Si) telah menjadi perhatian para peneliti karena biaya pembuatannya jauh lebih murah apabila dibandingkan dengan sel surya silikon kristal. Efisiensi konversi dari jenis silikon amorf tersebut pada saat ini telah mencapai lebih dari $13 \%$ Yang menjadi masalah adalah bagaimana usaha untuk menaikkan efisiensi konversi, yang salah satu caranya yaitu dengan menggunakan lapisan tipis konduktif yang transparan.

Ada beberapa jenis lapisan tipis konduksi transparan yaitu $\mathrm{SnO}_{2}$, ITO dan 
TCO. $\mathrm{SnO}_{2}$ harganya sangat murah, akan tetapi nilai resistivitasnya jauh lebih tinggi dari pada ITO (Indium Tin Oxide), sedangkan ITO merupakan campuran $\mathrm{SnO}_{2}$ dan $\mathrm{In}_{2} \mathrm{O}_{3}$; adapun perbandingan $\mathrm{Sn}$ : In sekitar $5: 95$. Keunggulan dari ITO adalah resistivitasnya rendah, tetapi proses pembuatan In sangat mahal. Oleh karena itu, pada saat ini dikembangkan lapisan tipis lainnya untuk lapisan konduktif transparan. Salah satu jenis bahan lapisan tipis TCO (Transparent Conducting Oxide) adalah ZnO. Lapisan tipis $\mathrm{ZnO}$ yang akan dicampur dengan sedikit $\mathrm{Al}$ adalah merupakan salah satu bahan TCO, karena itu selain resistivitasnya sangat rendah, harganya murah dan sifat-sifat optiknya yang baik, juga mempunyai kestabilan yang tinggi dalam plasma hidrogen dan dapat ditumbuhkan dalam suhu yang rendah.

Penelitian ini diharapkan memperoleh hasil lapisan tipis $\mathrm{ZnO}$ :Al yang akan dapat digunakan sebagai bahan TCO (Transparent Conducting Oxide) untuk sel surya silikon amorf. Untuk mendapatkan lapisan tipis ZnO:Al maka telah dilakukan variasi pembuatan target $\mathrm{ZnO}$ yang dicampur dengan sedikit Al, sehingga didapatkan hasil optimum pada target $\mathrm{ZnO}: \mathrm{Al}$ dengan campuran sekitar $(1,05 \%)$ berat $\mathrm{Al}$. Sifat-sifat optik (transmitansi) lapisan tipis ZnO:Al yang terdeposisi pada permukaan substrat gelas sangat tergantung pada parameter-parameter sputtering yaitu suhu substrat, tekanan gas dan waktu deposisi.

Penelitian ini telah dilakukan deposisi lapisan tipis ZnO:Al pada substrat gelas dengan metode sputtering. Untuk mendapatkan lapisan tipis $\mathrm{ZnO}: \mathrm{Al}$ yang optimum telah dilakukan variasi parameter sputtering yang meliputi suhu 200; 250; 300; 350; 400 dan $450{ }^{\circ} \mathrm{C}$, tekanan gas $6 \times 10^{-2}$ dan $8 \times 10^{-2}$ torr, lama waktu deposisi 1,5; 2 dan 2,5 jam

Metode yang dipakai untuk karakterisasi lapisan tipis adalah dengan peralatan UV-vis yang sangat tepat untuk menentukan prosentase nilai transmitansi sedangkan untuk mengetahui ketebalan lapisan dan morfologi permukaan dengan SEM.

\section{TATA KERJA}

Dalam penelitian ini yang dilakukan meliputi tahapan persiapan bahan cuplikan untuk substrat, pembuatan target $\mathrm{ZnO}$ yang dicampur dengan sedikit $\mathrm{Al}$ dan divariasi persen berat, persiapan peralatan untuk penelitian, pelaksanaan penelitian, pendeposisian lapisan tipis $\mathrm{ZnO}: \mathrm{Al}$ pada substrat gelas, karakterisasi sifat-sifat optik (transmitansi) hasil lapisan tipis $\mathrm{ZnO}: \mathrm{Al}$ dengan UV-vis, pengamatan struktur kristal dengan XRD ( $X$ Ray Difraction) dan analisis data dari foto struktur mikro yang diamati dengan SEM (Scanning Electron Microscopy).

\section{A. Persiapan Penelitian}

\section{Persiapan Bahan}

Bahan utama yang disiapkan dalam penelitian ini yaitu pembuatan bahan target serbuk ZnO yang dicampur dengan sedikit serbuk $\mathrm{Al}$ yang divariasi persen berat $\mathrm{Al}$ yaitu 0,$5 ; 0,79 ; 1,05 ; 1,32$ dan 1,59\%, kemudian dibuat dalam bentuk pelet. Dalam pembuatan pelet untuk target tersebut telah terbentuk lempeng bundar berdiameter $60 \mathrm{~mm}$, tebal $2 \mathrm{~mm}$ dan dilakukan dengan tekanan pengepresan 50 N. Sebelum dilakukan pengepresan, serbuk $\mathrm{ZnO}$ yang dicampur dengan sedikit $\mathrm{Al}$ diaduk-aduk dulu supaya kedua campuran bahan tersebut bisa merata atau homogen. Sedangkan bahan pendukung penelitian lainnya yang telah disiapkan terdiri dari gas Argon dan bahan gelas preparat yang digunakan sebagai substrat.

\section{Persiapan Peralatan Penelitian}

\section{a). Reaktor Plasma}

1. Tabung reaktor dari stainless steel yang dilengkapi dengan sebuah jendela kaca.

2. Pemegang target dan pemegang substrat.

3. Catu daya arus searah.

4. Alat ukur arus, tegangan dan vakum. 
5. Pompa vakum (rotari dan difusi).

6. Pemanas substrat.

7. Pendingin target.

\section{b). Alat-alat karakterisasi}

1. Karakterisasi sifat-sifat optik (transmitansi) dengan peralatan UV-vis

2. Peralatan XRD (Difraksi Sinar X).

3. Peralatan SEM (Scanning Electron Microscope).

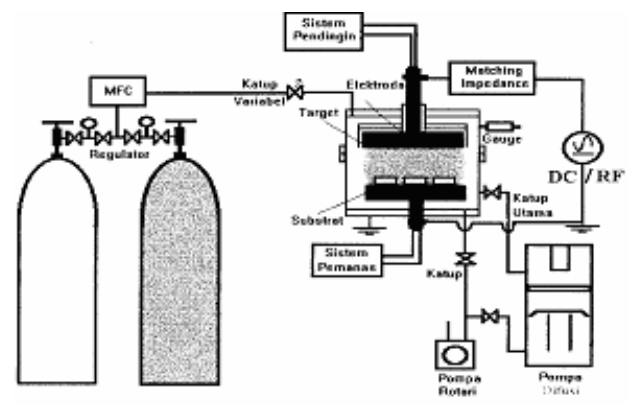

Gambar 1. Skema Sistem Deposisi Sputtering

\section{B. Pelaksanaan Penelitian}

\section{Pembuatan Substrat}

Substrat dibuat dari bahan gelas preparat yang dipotong-potong dengan ukuran $1 \mathrm{~cm} \times 2 \mathrm{~cm}$. Substrat tersebut dicuci dengan deterjen dan alkohol menggunakan ultrasonic cleaner. Setelah bersih substrat dibersihkan dengan tisue, dikeringkan dengan pemanas, kemudian dibersihkan lagi dengan aceton selanjutnya dimasukkan dalam pembungkus plastik klip.

\section{Pembuatan Lapisan Tipis ZnO:Al}

Pembuatan lapisan tipis $\mathrm{ZnO}: \mathrm{Al}$ dilakukan dengan metode sputtering DC dan skema peralatan seperti yang ditampilkan pada Gambar 1. Target ZnO:Al dipasang pada katode dan substrat diletakkan pada anode. Udara di dalam tabung reaktor divakumkan dengan pompa rotari dan difusi yang tekanannya sampai dengan $10^{-5}$ torr dapat digunakan untuk membersihkan partikel-partikel yang tidak dikehendaki. Setelah beberapa menit pompa vakum difusi dimatikan, kemudian gas argon dialirkan melalui kran, sehingga tekanan gas di dalam tabung reaktor akan naik menjadi $10^{-2}$ torr. Pada bagian katoda didinginkan dengan air pendingin supaya suhu pada target tidak naik karena tertumbuk ion argon. Kemudian pada bagian anoda (tempat substrat) justru dipanaskan untuk memperbesar frekuensi getaran atom substrat. Apabila penyedia daya tegangan tinggi DC dihidupkan, maka gas argon yang ada pada celah elektroda akan terionisasi. Ion argon akan menumbuki target $\mathrm{ZnO}: \mathrm{Al}$ dan ion argon akan bersenyawa dengan ion ZnO:Al dan menumbuk substrat. Lapisan tipis yang terdeposisi pada substrat kaca tergantung pada suhu substrat, tekanan gas dan lama waktu sputtering. Pada proses deposisi lapisan tipis $\mathrm{ZnO}: \mathrm{Al}$ ini, jarak anode dan katode $2 \mathrm{~cm}$, beda tegangan anode dan katode $2 \mathrm{kV}$, sedangkan parameter sputtering yaitu suhu substrat, tekanan gas, dan lama waktu deposisi sputtering, dilakukan sebagai berikut.

a. Pendeposisian dilakukan dengan menggunakan target $\mathrm{ZnO}$ :Al optimum yaitu campuran $(1,05) \%$ berat $\mathrm{Al}$.

b. Suhu substrat $=450{ }^{\circ} \mathrm{C}$, tekanan gas $=$ $6 \times 10^{-2}$ torr, waktu deposisi $=1,5$ jam, tegangan $=2 \mathrm{kV}$, arus $=10 \mathrm{~mA}$.

c. Pendeposisian dilakukan pada tegangan DC yang tetap $=2 \mathrm{kV}$.

\section{Karakterisasi}

Untuk pengukuran karakterisasi sifat-sifat optik (transmitansi) lapisan tipis ZnO:Al pada substrat gelas dilakukan dengan menggunakan peralatan Spektrofoto- meter UV-vis. Untuk pengamatan spektrum struktur kristal dilakukan dengan alat XRD, sedangkan untuk mengetahui struktur mikro lapisan tipis ZnO:Al diamati menggunakan peralatan Scanning Electron Microscopy (SEM). 


\section{HASIL DAN PEMBAHASAN}

Dalam penelitian ini bahan cuplikan yang dideposisi dengan lapisan tipis $\mathrm{ZnO}: \mathrm{Al}$ adalah gelas preparat. Untuk mendapatkan lapisan tipis $\mathrm{ZnO}$ :Al pada substrat gelas yang mempunyai sifat-sifat optik (transmitansi) yang optimum tergantung pada suhu substrat, tekanan gas dan lama waktu deposisi. Pembuatan lapisan tipis $\mathrm{ZnO}: \mathrm{Al}$ pada permukaan substrat gelas dilakukan dengan variasi suhu, tekanan gas, lama waktu deposisi dan menggunakan metode sputtering. Dari hasil pengukuran karakterisasi sifat-sifat optik (transmitansi) lapisan tipis $\mathrm{ZnO}$ :Al pada substrat gelas pada suhu $450{ }^{\circ} \mathrm{C}$, tekanan gas $=6 \times 10^{-2}$ torr, lama waktu deposisi $=1,5$ jam dengan peralatan UV-vis ditunjukkan dalam Gambar 3, 4 dan 5, sedangkan untuk transmitansi lapisan tipis ZnO murni ditunjukkan dalam Gambar 2.

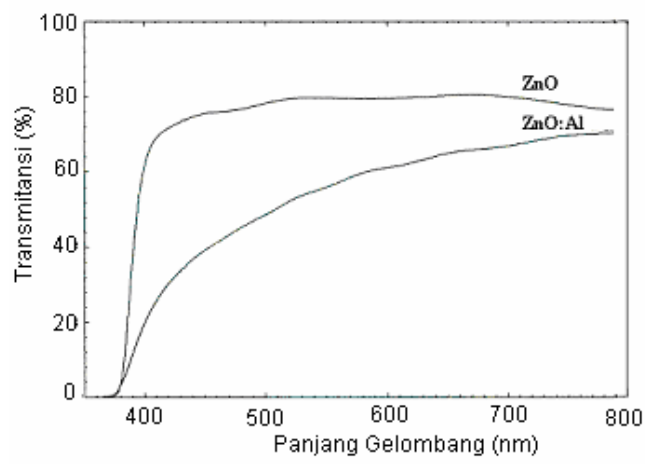

Gambar 2. Hubungan transmitansi vs panjang gelombang untuk lapisan tipis $\mathrm{ZnO}$ murni pada suhu 450 ${ }^{\circ} \mathrm{C}$, tekanan $6 \times 10^{-2}$ torr, waktu deposisi 1,5 jam dengan peralatan UV-vis.

Pada Gambar 2 telah menunjukkan bahwa untuk lapisan tipis $\mathrm{ZnO}$ murni dihasilkan nilai transmitansi sekitar (62-80) \%. Nilai transmitansi ini dihitung pada posisi panjang gelombang (400-800) nm. Apabila dihitung pada posisi panjang gelombang (500-800) nm, nilai transmitansinya sekitar (78 - 80) \%.
Hasil pengukuran karakterisasi sifat-sifat optik (transmitansi) lapisan tipis $\mathrm{ZnO}$ :Al pada substrat gelas untuk variasi suhu (300-450) ${ }^{\circ} \mathrm{C}$, pada tekanan $6 \times 10^{-2}$ torr, lama waktu deposisi 1,5 jam ditunjukkan dalam Gambar 3.

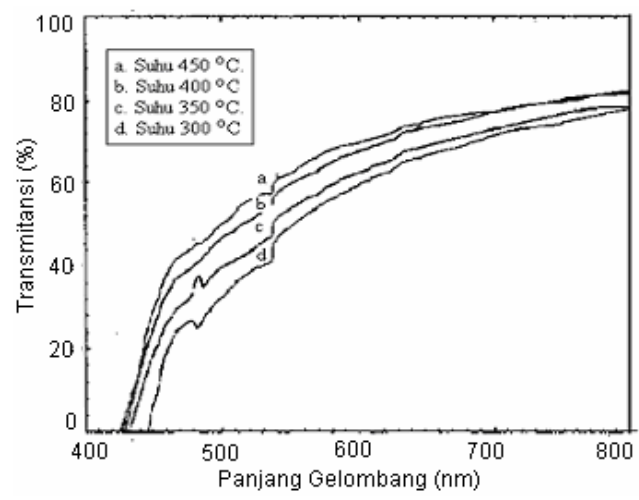

Gambar 3. Hubungan transmitansi vs panjang gelombang untuk variasi suhu pada tekanan $6 \times 10^{-2}$ torr dan waktu deposisi 1,5 jam dengan UV-vis.

Lapisan tipis $\mathrm{ZnO}: \mathrm{Al}$ pada Gambar 3 untuk variasi suhu $(300-450){ }^{\circ} \mathrm{C}$ tersebut diatas dihasilkan nilai transmitansi sekitar (32-50) \%, pada posisi panjang gelombang 500 nm, sekitar (66-75) \% pada posisi panjang gelombang $650 \mathrm{~nm}$ dan sekitar (77-82) \% pada posisi panjang gelombang $800 \mathrm{~nm}$. Untuk variasi suhu dalam penelitian ini diperoleh hasil nilai transmitansi optimum sekitar (50-82) \% pada suhu $450{ }^{\circ} \mathrm{C}$ dan pada posisi panjang gelombang (500-800) nm. Dengan naiknya suhu, maka deposisi lapisan tipis $\mathrm{ZnO}: \mathrm{Al}$ yang terbentuk dalam proses sputtering akan semakin berkurang karena dalam proses tersebut terjadi penguapan sehingga nilai transmitansinya semakin tinggi.

Hasil pengukuran karakterisasi sifat-sifat optik (transmitansi) lapisan tipis $\mathrm{ZnO}$ :Al pada substrat gelas untuk variasi tekanan gas $(6-8) \times 10^{-2}$ torr, pada suhu 450 ${ }^{\circ} \mathrm{C}$ dan waktu deposisi 1,5 jam ditunjukkan dalam Gambar 4. Karakterisasi lapisan tipis 
ZnO:Al pada Gambar 4 untuk variasi tekanan gas dibawah ini diperoleh hasil nilai transmitansi sekitar (50-27) \%, pada posisi panjang gelombang $500 \mathrm{~nm}$, sekitar (7458) \% pada posisi panjang gelombang 650 $\mathrm{nm}$, dan sekitar (80-70) \% pada panjang gelombang $800 \mathrm{~nm}$.

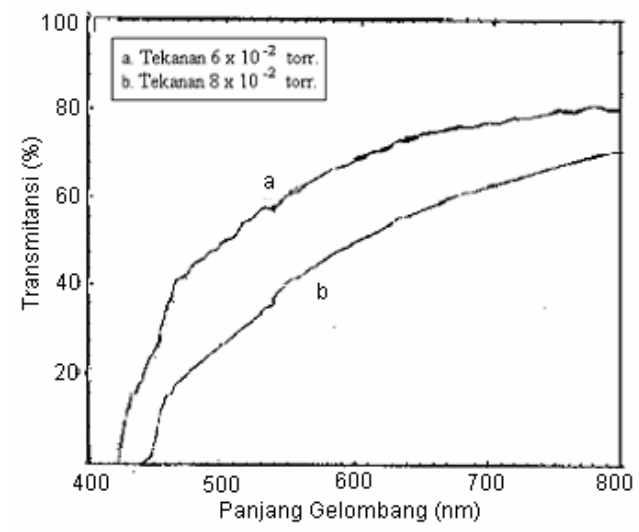

Gambar 4. Hubungan transmitansi vs panjang gelombang untuk variasi tekanan pada suhu $450{ }^{\circ} \mathrm{C}$ dan waktu deposisi 1,5 jam dengan peralatan UV-vis.

Untuk variasi tekanan dalam penelitian ini diperoleh hasil nilai transmitansi optimum sekitar (50-80) \% pada tekanan gas $6 \times 10^{-2}$ torr dan pada posisi panjang gelombang (500-800) nm. Dengan semakin tinggi tekanan, maka semakin banyak gas argon yang keluar, sehingga lapisan tipis ZnO:Al yang terdeposisi akan semakin tebal dan nilai transmitansinya semakin rendah (turun).

Hasil pengukuran karakterisasi sifat-sifat optik (transmitansi) lapisan tipis ZnO:Al pada substrat gelas untuk variasi waktu deposisi $(1,5-2,5)$ jam pada suhu 450 ${ }^{\circ} \mathrm{C}$ dan tekanan $6 \times 10^{-2}$ torr ditunjukkan dalam gambar 5 .

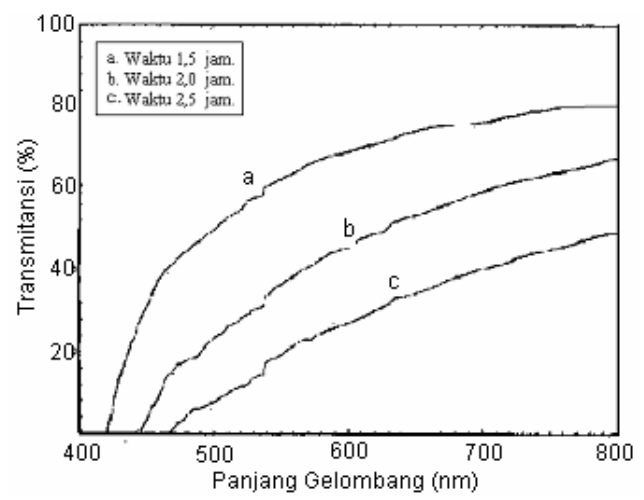

Gambar 5. Hubungan transmitansi vs panjang gelombang untuk variasi waktu deposisi pada suhu 450 ${ }^{\circ} \mathrm{C}$ dan tekanan $6 \times 10^{-2}$ torr dengan peralatan $U V$-vis.

Lapisan tipis ZnO:Al pada Gambar 5 untuk variasi waktu deposisi $(1,5-2,5)$ jam tersebut diatas dihasilkan nilai transmitansi sekitar (49-7) \%, pada panjang gelombang 500 nm, sekitar (74-34) \% pada posisi panjang gelombang $650 \mathrm{~nm}$ dan sekitar (81- 50) \% pada panjang gelombang $800 \mathrm{~nm}$. Untuk variasi waktu deposisi dalam penelitian ini diperoleh hasil nilai transmitansi optimum sekitar (49-81) \% pada lama waktu deposisi 1,5 jam dan pada posisi panjang gelombang (500-800) $\mathrm{nm}$. Dengan naiknya lama waktu deposisi, maka ketebalan lapisan tipis $\mathrm{ZnO}$ :Al yang terbentuk semakin meningkat sehingga nilai transmitansinya semakin turun.

Hasil nilai transmitansi lapisan tipis ZnO pada suhu, tekanan, waktu tersebut diatas sekitar (78-80) \%. Sedangkan untuk lapisan tipis $\mathrm{ZnO}$ :Al nilai transmitansi optimum sekitar (50-82) \% untuk suhu 450 ${ }^{\circ} \mathrm{C}$, sekitar (50-80) \% untuk tekanan $6 \times 10^{-2}$ torr dan sekitar (49-81) \% untuk waktu 1,5 jam. Lapisan tipis $\mathrm{ZnO}$ mempunyai nilai transmitansi optimum lebih besar bila dibandingkan dengan transmitansi lapisan tipis $\mathrm{ZnO}: \mathrm{Al}$, karena lapisan tipis $\mathrm{ZnO}$ mempunyai sifat tembus cahaya yang cukup besar. Sedangkan lapisan tipis $\mathrm{ZnO}: \mathrm{Al}$ ini adalah lapisan tipis $\mathrm{ZnO}$ yang dikotori 
dengan sedikit $\mathrm{Al}$ dan aluminium tidak mempunyai sifat tembus cahaya tetapi bisa memantulkan cahaya. Dengan demikian lapisan tipis $\mathrm{ZnO}$ yang dikotori dengan sedikit Al akan berkurang nilai transmitansinya.

Tabel 1. Hasil transmitansi optimum lapisan tipis $\mathrm{ZnO}$ murni dan $\mathrm{ZnO}$ :Al dengan peralatan UV-vis pada posisi panjang gelombang $(500-800) \mathrm{nm}$

\begin{tabular}{|l|l|c|c|}
\hline No & BAHAN TARGET & SUHU, TEKANAN, WAKTU & TRANSMITANSI (\%) \\
\hline 1. & Zn O murni & $\left(450^{\circ} \mathrm{C}, 6 \times 10^{-2}\right.$ torr, $\left.1,5 \mathrm{jam}\right)$ & $(78-80)$ \\
\hline 2 & Campuran ZnO:Al & $\left(450^{\circ} \mathrm{C}, 6 \times 10^{-2}\right.$ torr, $\left.1,5 \mathrm{jam}\right)$ & $(50-82)$ \\
\hline 3. & Campuran ZnO:Al & $\left(450^{\circ} \mathrm{C}, 6 \times 10^{-2}\right.$ torr, $\left.1,5 \mathrm{jam}\right)$ & $(50-80)$ \\
\hline 4. & Campuran $\mathrm{ZnO}: \mathrm{Al}$ & $\left(450^{\circ} \mathrm{C}, 6 \times 10^{-2}\right.$ torr, $\left.1,5 \mathrm{jam}\right)$ & $(49-81)$ \\
\hline
\end{tabular}

Dalam penelitian ini juga dilakukan pengamatan struktur mikro atau morfologi permukaan lapisan $\mathrm{ZnO}$ dan $\mathrm{ZnO}$ :Al pada kondisi optimum, yaitu pada suhu substrat $450{ }^{\circ} \mathrm{C}$, tekanan $6 \times 10^{-2}$ torr dan waktu deposisi 1,5 jam. Struktur mikro tersebut dilakukan karena menentukan sifat-sifat optik khususnya nilai transmitansi lapisan $\mathrm{ZnO}$ dan $\mathrm{ZnO}$ :Al.

Hasil foto SEM, ketebalan dan morfologi permukaan dari lapisan tipis $\mathrm{ZnO}$ pada suhu $450{ }^{\circ} \mathrm{C}$, tekanan $6 \times 10^{-2}$ torr dan lama waktu deposisi 1,5 jam dengan perbesaran 10.000 kali ditunjukkan dalam Gambar 6.

Berdasarkan gambar 6(a). diperoleh tebal lapisan $\mathrm{ZnO}$ sekitar 1,5 $\mu \mathrm{m}$, dan dari gambar 6(b). dapat dilihat bahwa lapisan $\mathrm{ZnO}$ yang terbentuk dari butiran-butiran kecil yang terdistribusi secara homogen. Sedangkan gambar 7(a). memperlihatkan bahwa tebal lapisan ZnO:Al adalah 1,3 $\mu \mathrm{m}$, dan Gambar 7(b) menampilkan struktur mikro dengan butiran-butiran yang tidak homogen. Hasil pengamatan struktur mikro tersebut menentukan sifat optik lapisan, terutama nilai transmitansinya seperti ditampilkan dalam Gambar 2, 3, 4 dan 5

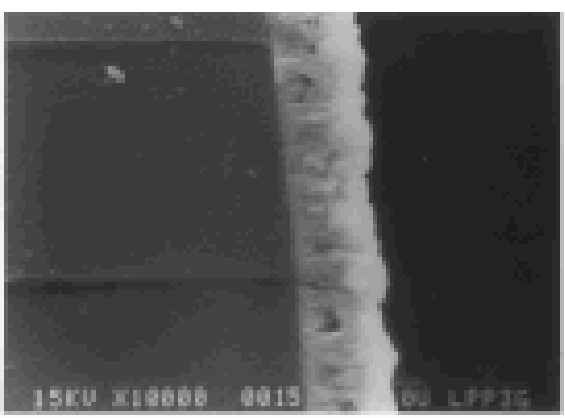

a.

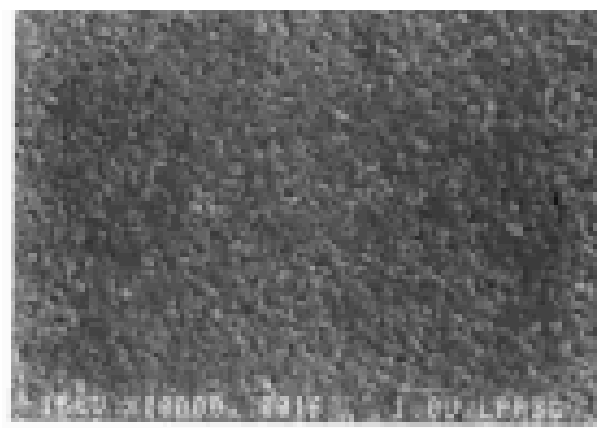

b

Gambar 6. Hasil foto SEM ketebalan lapisan tipis $\mathrm{ZnO}$ (a) dan morfologi permukaan lapisan tipis $\mathrm{ZnO}$ (b) pada tekanan $6 \times 10^{-2}$ torr, suhu $450{ }^{\circ} \mathrm{C}$ dan waktu deposisi 1,5 jam dengan perbesaran $10.000 \times$

Hasil foto SEM ketebalan dan struktur mikro dari lapisan tipis $\mathrm{ZnO}: \mathrm{Al}$ pada tekanan $6 \times 10^{-2}$ torr, suhu $450{ }^{\circ} \mathrm{C}$ dan lama waktu deposisi 1,5 jam dengan 
perbesaran 10.000 kali ditunjukkan dalam Gambar 7.

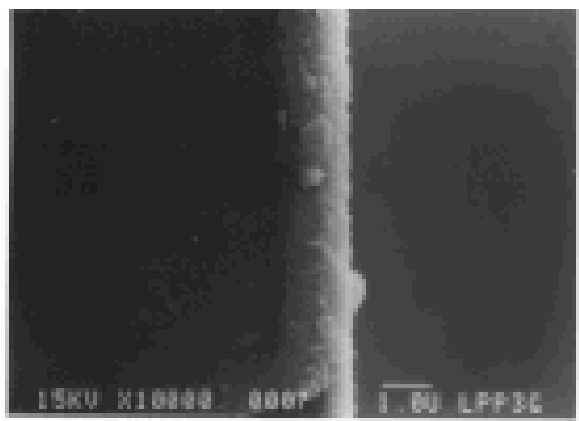

a.

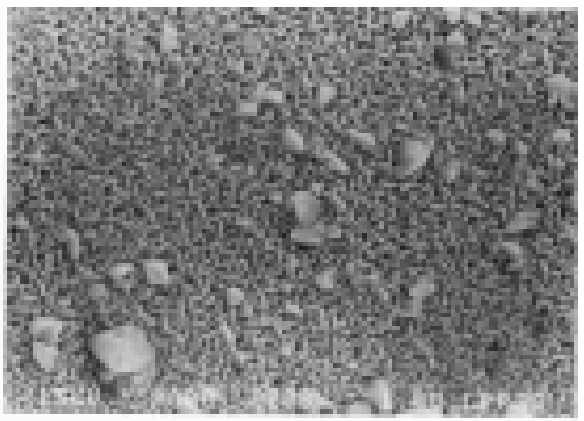

b.

Gambar 7. Hasil foto SEM ketebalan lapisan tipis $\mathrm{ZnO}: \mathrm{Al}$ (a) dan struktur mikro (b) pada tekanan $6 \times 10^{-2}$ torr, suhu 450 ${ }^{\circ} \mathrm{C}$ dan waktu deposisi 1,5 jam dengan perbesaran 10.000 kali.

\section{KESIMPULAN}

1. Karakterisasi sifat-sifat optik (transmitansi) lapisan tipis pada substrat gelas dengan UV-vis diperoleh hasil nilai transmitansi optimum sekitar (78-80) \% untuk lapisan tipis $\mathrm{ZnO}$ murni pada suhu $450{ }^{\circ} \mathrm{C}$, tekanan $6 \times 10^{-2}$ torr, waktu deposisi 1,5 jam dan pada posisi panjang gelombang (500-800) nm.

2. Karakterisasi sifat-sifat optik untuk varisai suhu diperoleh hasil nilai transmitansi optimum sekitar
(50-82) \% pada suhu $450{ }^{\circ} \mathrm{C}$, tekanan $6 \times 10^{-2}$ torr, waktu deposisi 1,5 jam dan pada posisi panjang gelombang (500-800) nm.

3. Karakterisasi sifat optik untuk variasi tekanan gas diperoleh hasil nilai transmitansi optimum sekitar (50-80) \% pada tekanan gas $6 \times 10^{-2}$ torr, suhu $450{ }^{\circ} \mathrm{C}$ waktu deposisi 1,5 jam dan pada posisi panjang gelombang (500-800) nm.

4. Karakterisasi sifat optik untuk variasi lama waktu deposisi diperoleh hasil nilai transmitansi optimum sekitar (49-81) \% pada lama waktu deposisi 1,5 jam, suhu $450{ }^{\circ} \mathrm{C}$, tekanan $6 \times 10^{-2}$ torr dan pada posisi panjang gelombang (500-800) nm

5. Hasil analisa foto dengan SEM, untuk lapisan tipis $\mathrm{ZnO}$ diperoleh tebal lapisan sekitar 1,5 $\mu \mathrm{m}$, morfologi permukaan dan butiran-butiran kecil terdistribusi secara homogen. Sedangkan untuk lapisan tipis $\mathrm{ZnO}: \mathrm{Al}$ diperoleh tebal lapisan sekitar $1,3 \mu \mathrm{m}$ dan morfologi permukaan yang terbentuk dengan butiran-butiran yang tidak seragam.

\section{UCAPAN TERIMA KASIH}

Pada kesempatan ini penulis mengucapkan terima kasih yang setulustulusnya kepada saudara Drs. Tjipto Suyitno, MT atas sumbang saran dan diskusi ilmiahnya tentang penelitian ini.

\section{DAFTAR PUSTAKA}

1. KATSUYA TABUCHI, WILSON W. WENAS, MASAHIRO YOSHINO, A. YAMADA, "Optimation of $\mathrm{ZnO}$ Film for Amorphous Silicon Solar Cells", 11 th European Photovoltaic Solar Energy Conference and Exhibition, Montreux, Switzerland, 12-16 October 1992.

2. KATSUYA TABUCHI, WILSON W. WENAS, AKIRA YAMADA, "Optimization of $\mathrm{ZnO}$ Film for 
Amorphous Silicon Solar Cells", Jpn, J. Appl. Phys, Vol, 32 (1993), Part I, No. 9A, 3764-3769.

3. K. TAKAHASHI AND M. KONAGAI, "Amorphous Silicon Solar Cells", North Oxford Academic Publishers Ltd, (1986).

4. MAKOTO KONAGAI, "Device Physics and Optimum Design of (a-Si) Solar Cell", 5 th "Sunshine" Workshop on Solar Cells, December 8-9, (1992), Tokyo, Japan.
5. TADATSUGU MINAMI, HIDEO SONOHARA, SHINZO TAKATA AND ICHIRO FUKUDA, "Low Temperature Formation of Textured ZnO Transparent Electrodes by Magnetron Sputtering", J. Vac. Sci. Technol. A 13 (3), May/Jun (1995). 